Indonesian Journal of Biotechnology, June, 2014

Vol. 19, No. 1, pp.64-70

\title{
Phylogenetic relationship of Gram Negative Bacteria of Enterobacteriaceae Family in the Positive Widal Blood Cultures based on 16S rRNA Gene Sequences
}

\author{
Sri Darmawati ${ }^{1}$, Langkah Sembiring ${ }^{2}$, Widya Asmara ${ }^{3}$, Wayan T. Artama ${ }^{4}$ \\ and Masashi Kawaichi ${ }^{5}$
}

\footnotetext{
${ }^{1}$ Microbiology Laboratory of Health and Nursing Faculty of Universitas Muhamadiyah Semarang.

${ }^{2}$ Microbiology Laboratory of Biology Faculty of Universitas Gadjah Mada, Yogyakarta

${ }^{3}$ Microbiology Department of Veterinary Faculty of Universitas Gadjah Mada, Yogyakarta

${ }^{4}$ Biochemistry Department of Veterinary Faculty of Universitas Gadjah Mada, Yogyakarta

${ }^{5}$ Laboratory of Gene Function in Animals, Graduate School of Biological Science, Nara Institute of Science and Technology, Nara, Japan
}

\begin{abstract}
The purpose of this study was to analyze the phylogenetic relationship of Gram negative bacteria (3 strains of Salmonella typhi, 1 strain of Escherichia coli, 1 strain of Serratia marcescens, and 3 strains of Enterobacter cloacae) of Enterobacteriaceae family in positive Widal blood cultures based on 16S rRNA gene sequences. The results respectively showed that each two 16S rRNA gene clones of Serratia marcescens KD 08.4 had a close relationship with 16S rRNA gene of Serrratia marcescens ATCC 13880 (similarity: 99.53-99.8\%), Eschericia coli BA 30.1 with Eschericia coli ATCC $11775^{\mathrm{T}}$ (similarity: 99.38-99.67\%), Salmonella typhi BA 07.4, Salmonella typhi KD 30.4, and Salmonella typhi SA 02.2 with Salmonella typhi ATCC 19430 (similarity: 99.4-100\%) as well as the isolates of Enterobacter cloacae SA 02.1, Enterobacter cloacae BA 45.4.1, one 16S rRNA gene clone of Enterobacter cloacae TG 03.5 with Enterobacter cloacae ATCC 23373 (similarity: 99.0-99.87\%).
\end{abstract}

Keywords: Widal, Enterobacteriaceae, $16 \mathrm{~S}$ rRNA genes

\section{Introduction}

The typhoid fever incidence rate in Indonesia had reached 358-810/100.000 population/year with the mortality rate of $1-5 \%$ of patients (Anonymous, 2007). In Semarang, typhoid fever had been in the third rank of 10 major diseases after Dengue Fever and Diarrhea and gastroenteritis (Anonymous, 2008). Typhoid fever was a serious systemic infectious disease that was possibly accompanied by a variety of diseases such as dengue fever and malaria (Gasem et al., 2002).

\section{* Corresponding Author:}

Sri Darmawati, Microbiology Laboratory, Nursing and Health Faculty, Muhammadiyah University of Semarang. $18^{\text {th }}$ Kedungmundu Raya Street. Semarang. E-mail: ciciekdarma@yahoo.com, Phone: 08122503552
The clinical features of typhoid fever were unspecific that the gold standard diagnosis could not only depend on the clinical symptoms but it should also be supported by the laboratory diagnosis (Khoharo et al., 2010; Ley et al., 2010; Fadeel et al., 2011). The gold standard diagnosis of typhoid fever was by the finding of Salmonella typhi (S. typhi) in blood or bone marrow cultures (Khoharo et al., 2010; Ley et al., 2010). However, the facilities for culturing of bacteria were not always available, it was expensive, time consuming (seven days) and the result was frequently negative since the patients had consumed antibiotics. Widal test was a widely used laboratory test in Indonesia supporting the typhoid fever diagnosis as it was cheap, easy, fast, and simple. The sensitivity, specificity, 
and predictive values of Widal test were various, due to the presence of anti-O and anti-H antibodies in patients infected by Salmonella sp., species of Enterobacteriaceae family member other than Salmonella $s p$. and malaria (Novianti, 2006; Beig et al., 2010). Darmawati et al., 2012, stated that there was bacterial species diversity of Enterobacteriaceae family members of such as S. typhi, Serratia marcescens, Escherichia coli, Enterobacter cloacae, Klebsiella pneumoniae in positive Widal blood cultures from Semarang. However, the phylogenetic relationship between species was unknown. Thus, the purpose of this study was to determine the phylogenetic relationship of Gram-negative bacillus bacteria of Enterobacteriaceae family members based on $16 \mathrm{~S}$ rRNA gene sequences.

\section{Materials And Methods \\ Bacterial Strains}

There was a total of 8 isolates ( 3 isolates of Salmonella typhi, 1 isolate of Escherichia coli, 1 isolates of Serratia marcescens, and 3 isolates of Enterobacter cloacae) isolated from positive Widal blood samples of in and outpatients from Semarang (Tugurejo hospital, City Hospital of Semarang, Sultan Agung Islamic Hospital, Community Health Center of Bangetayu, and Community Health Center of Kedungmundu). The bacterial Identification used API 20E and API 50CHB/E media (Darmawati, et al., 2012).

\section{DNA bacterial Extraction, PCR amplification, cloning, and DNA plasmid extraction with insertion and sequencing \\ DNA was extracted from eight bacterial} strains used DNeasy Blood E Tissue Kits (Qiagen, K69504). The 16S rRNA gene amplification used Applied Biosystems

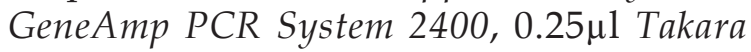
Ex Taq, $5 \mu 1$ 10X Ex Taq buffer, $4 \mu \mathrm{d}$ dNTP Mixture (2.5 mM each), $2 \mu$ l DNA template, $0.5 \mu \mathrm{l}$ primer $8 \mathrm{~F}(1.0 \mu \mathrm{M}$ final conc. $)$, and $0.5 \mu \mathrm{l}$ primer $4192 \mathrm{R}(1.0 \mu \mathrm{M}$ final conc.), $37.75 \mu \mathrm{l}$ sterile deionized water, for a total volume of $50 \mu 1$. The thermal cyling was as follows: denaturation at $95^{\circ} \mathrm{C}$ for $30 \mathrm{sec}$, annealing at $55^{\circ} \mathrm{C}$ for $30 \mathrm{sec}$, extension at $72^{\circ} \mathrm{C}$ for 1,5 $\mathrm{min}$, and final extention $72^{\circ} \mathrm{C}$ for $10 \mathrm{~min}$ for the total of 30 cycles. PCR products (1500bp) were visualilized through electrophoresis at $1 \%$ agarose gel with ethidium bromide added directly to the gel.

The amplified DNA bands were purified from agarose using glass powder method (Volgstein and Gillespie, 1979), ligated to T-Vector pMD20 (Takara Biotechnology), and transformated to E.coli DH5a. The plasmid DNA containing inserts was isolated, respectively amplified using primer M13 reverse, U515F, and M13-40 (Table 1). The amplified DNA were sequenced using primer M13 reverse, U515F, and M13-40. The DNA Sequencing was conducted with sequencer device of $A B I$ Prism $^{\mathrm{TM}} 310$ Genetic Analizer. The sequenced data were in the form of electrophenogram files and base DNA arrangement.

Tabel 1. Primer for 16S rRNA gene amplification dan sequencing

\begin{tabular}{ll}
\hline \multicolumn{1}{c}{ Primer } & \multicolumn{1}{c}{ Sequences } \\
\hline 8F & 5'-AGA GTT TGA TCC TGG CTC AG-3' \\
1492 R & 5'-AAG TCG TAA CAA GGT AAC C-3' \\
M13-RV & 5'-CAG GAA ACA GCT ATG AC-3' \\
U515F & 5'-GTG CCA GCA GCC GCG GTA A-3' \\
M13-40 & 5'-GTT TTC CCA GTC ACG AC-3' \\
\hline
\end{tabular}

\section{Analysis and alignment of $16 S$ rRNA gene sequences}

The 16S rRNA sequence were analyzed and compared to the Gene Bank nucleotide database using Basic Local Alignment Search Tool (BLAST). The 16S rRNA Sequences of 8 bacterial strains were aligned using CLUSTAL $X$ program.

\section{Phylogenetic tree Construction}

Phylogenetic tree was prepared using PHYLIP program, matrix similarity, and nucleotide difference of 16S rRNA between clones and strains analyzed with PHYDIT program. 


\section{Results And Discussion}

The results of $16 \mathrm{~S}$ rRNA gene amplification of 8 isolates of Enterobacteriaceae family members were shown in Figure 1 while the results of phylogenetic relationship analysis based on 16S rRNA gene sequences were shown in Figure 2. There was a total of 15 sequences with each isolate consisted of two 16S rRNA gene sequences derived from two

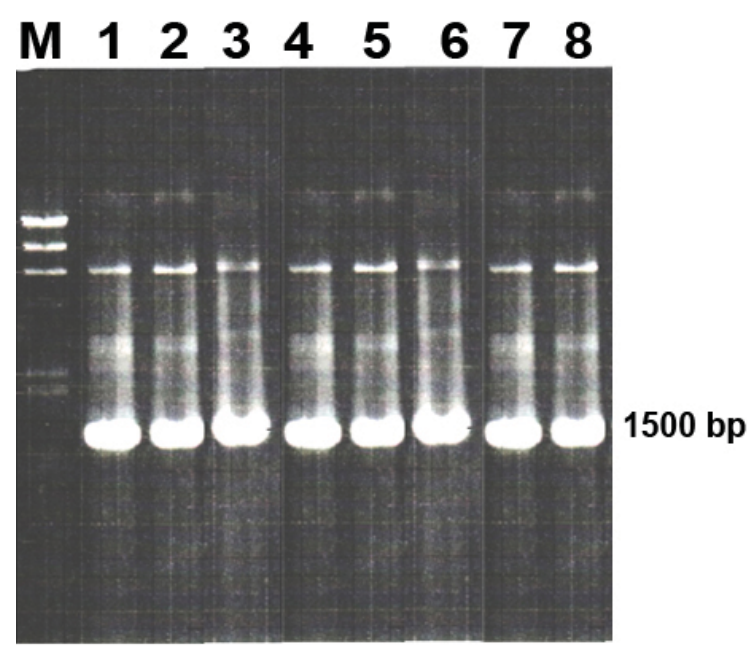

Figure 1. The results of $16 \mathrm{~S}$ rRNA gene amplification of 8 bacterial isolates: (M) DNA Hind Marker III, (1) S. typhi SA 02.2, (2) S. typhi BA 07.4, (3) S. typhi KD 30.4, (4) Ser. marcescens KD 08.4, (5) E. coli BA 30.1, (6) Ent. cloacae SA 02.1, (7) Ent. cloacae TG 03.5, (8) Ent. cloacae BA 45.4.1 clones of $16 \mathrm{~S}$ rRNA gene sequences except TG 03.5 isolate and 5 sequences derived from $16 S$ rRNA sequences of Gram-negative bacillus bacteria of Enterobacteriaceae family (Gene Bank, NCBI) consisting of $S$. typhi strain types of ATCC $19430^{\mathrm{T}}$ (accession no. Z47544), E. coli $11775^{\mathrm{T}}$ (X80725.1), Ent. cloacae ATCC 23373 (HQ651841.1), Citrobacter freundii ATCC 8090 (AJ233408.1), Ser. marcescens ATCC 13880 (AB594756.1). Two strains as out group used Vibrio cholerae ATCC 14547 (NR_044050.1) from Vibrionaceae family (negative catalase and positive oxidase) and Pseudomonas aeruginosa ATCC 23993 (FJ652615.1) from Pseudomonadaceae family (positive catalase and oxidase).

After the 16S rRNA gene sequences was aligned with Clustal-X program, the phylogenetic trees were arranged using PHYLIP program

The phylogenetic relationship analysis of 15 16S rRNA gene clones of 8 isolates (Figure 2 ) was divided into five clades. The first clade consisted of 6 16S rRNA gene clones derived from 3 isolates (SA 02.2, KD 30.4, and BA 07.4) and 2 reference strains: $S$. typhi ATCC 19430 and Ent. cloacae ATCC 23373. The similarity value of those six clones with $S$. typhi ATCC $19430^{\mathrm{T}}$ was 99.4 to $100 \%$ with the difference of 0-9 nucleotide, shown in Table 2.

Table 2. Matrix similarity and nucleotide difference of 16S rRNA gene sequences of Gram negative bacillus bacteria of Enterobacteriaceae family members on the first clade with reference strains of S. typhi ATCC 19430

\begin{tabular}{|c|c|c|c|c|c|c|c|c|}
\hline Isolate Code & $\begin{array}{l}\text { U్ } \\
\text { ป } \\
\text { ऊ } \\
\text { ऊ }\end{array}$ & 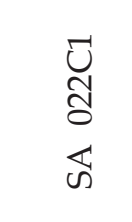 & 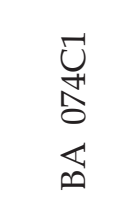 & 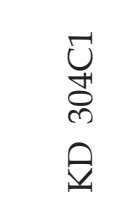 & 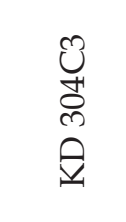 & 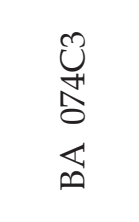 & 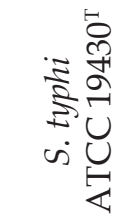 & 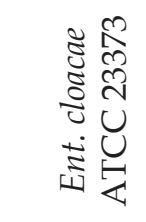 \\
\hline SA022C3 & --- & $4 / 1502$ & $2 / 1503$ & $2 / 1503$ & $9 / 1500$ & $5 / 1500$ & $9 / 1503$ & $27 / 1498$ \\
\hline SA022C1 & 99.73 & --- & $2 / 1502$ & $2 / 1502$ & $9 / 1499$ & $5 / 1499$ & $9 / 1502$ & $27 / 1497$ \\
\hline BA074C1 & 99.87 & 99.87 & --- & $0 / 1503$ & $7 / 1500$ & $3 / 1500$ & $7 / 1503$ & $25 / 1498$ \\
\hline KD304C1 & 99.87 & 99.87 & 100 & --- & $7 / 1500$ & $3 / 1500$ & $7 / 1503$ & $25 / 1498$ \\
\hline KD304C3 & 99.4 & 99.4 & 99.53 & 99.53 & --- & $6 / 1499$ & $9 / 1500$ & 28/1495 \\
\hline BA074C3 & 99.67 & 99.67 & 99.8 & 99.8 & 99.6 & --- & $3 / 1500$ & 22/1495 \\
\hline S. typhi ATCC 19430T & 99.4 & 99.4 & 99.53 & 99.53 & 99.4 & 99.8 & --- & $27 / 1504$ \\
\hline Ent. cloacae ATCC23373 & 98.2 & 98.2 & 98.33 & 98.33 & 98.13 & 98.53 & 98.2 & --- \\
\hline
\end{tabular}




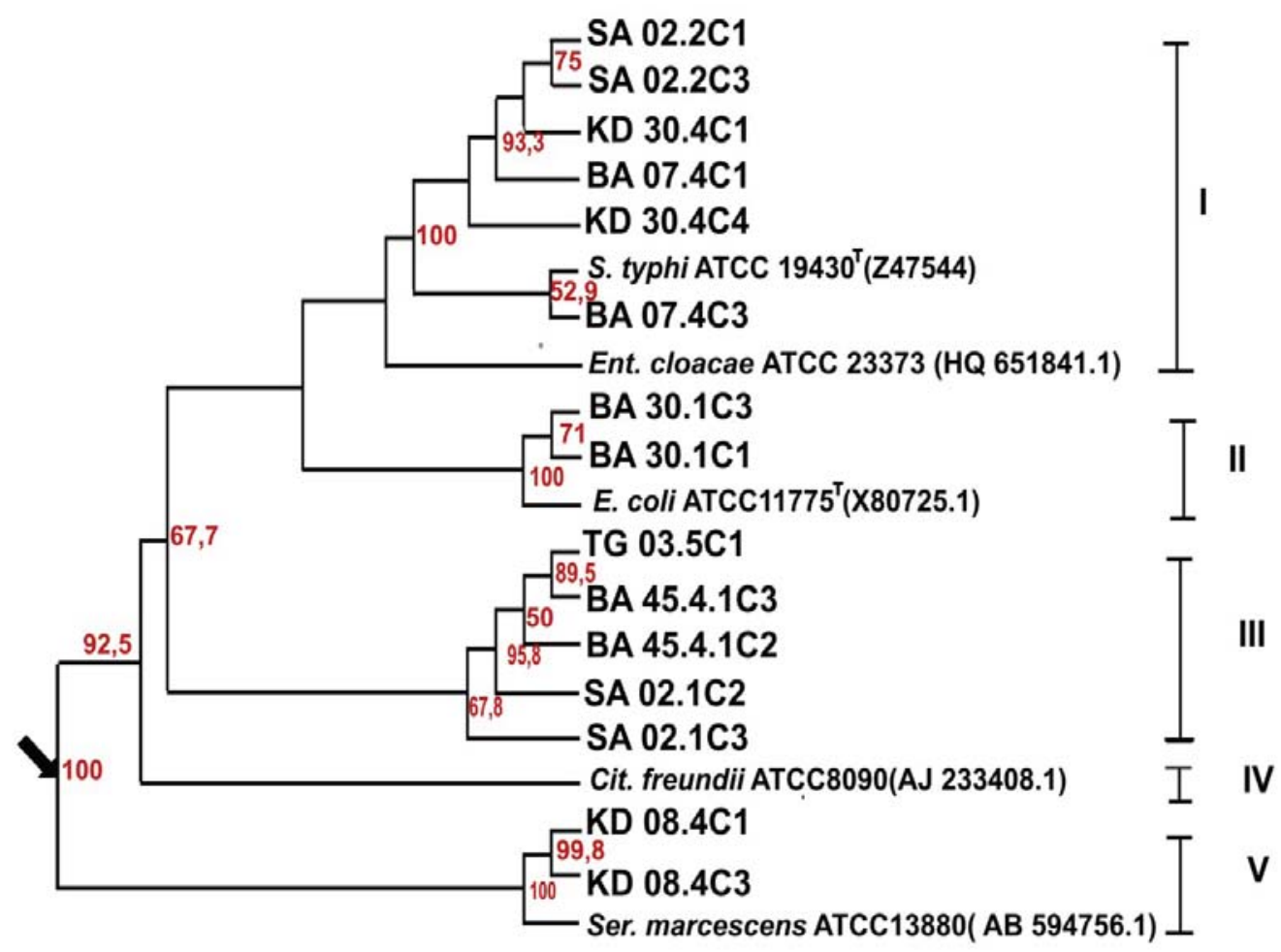

Figure 2. The phylogenic tree constructed based on Algoritme Neighbour Joining (Saitou and Nei, 1987) showing the kinship relationship between 8 isolates (15 clones of 16S rRNA) of Gram negative bacillus bacteria of Enterobacteriaceae family members, with 5 bacterial strains of Enterobacteriaceae members as reference based on 16S rRNA gene sequences. The root site determination was using outgroup of Vibrio cholera strain ATCC 14547 of Vibrionaceae family members and Pseudomonas aeruginosa strain ATCC 23943 of Pseudomonadaceae family members.

Based on the nucleotide similarity value, it could be concluded that isolate SA 02.2, KD 30.4, and BA 07.4 were identified as $S$. typhi members. Two different $16 \mathrm{~S}$ rRNA clones, derived from one isolate also showed the presence of nucleotide differences of 3-7 (Similarity 99.53 to $99.80 \%$ ).

The second clade consisted of two 16S rRNA gene clones derived from one isolate BA 30.1, with reference strain of E. coli ATCC $19430^{\mathrm{T}}$ in the similarity value between 99.38 to $99.67 \%$ with nucleotide differences of 5-9 (Table 3). The isolate BA 30.1, based on its close relationship with the reference strain was identified as E. coli members.

The third clade consisted of five $16 \mathrm{~S}$ rRNA gene clones derived from 3 isolates (BA 45.4.1, SA 02.1 and TG 03.5). The relationship between three bacterial isolates from Bangetayu Community health center,
Tugurejo hospital and Sultan Agung Islamic Hospital showed the similarity value of $99.0-99.87 \%$ with nucleotide difference of 2-15 (Table 4), which had the closest kinship relationship with Ent. cloacae ATCC 23373.

Table 3. Matrix similarity and nucleotide difference of $16 \mathrm{~S}$ rRNA gene sequences of Gram negative bacillus bacteria of Enterobacteriaceae family members on the second clade and reference strain of E. coli ATCC $19430^{\mathrm{T}}$

\begin{tabular}{|c|c|c|c|}
\hline \multirow[t]{2}{*}{ Isolate Code } & $\begin{array}{l}\tilde{U} \\
\dot{\sigma} \\
\dot{0}\end{array}$ & $\begin{array}{l}0 \\
0 \\
0 \\
0\end{array}$ & 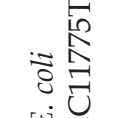 \\
\hline & $\underset{\varnothing}{\circledR}$ & $\underset{\infty}{\ll}$ & 幽 \\
\hline BA 301C1 & --- & $5 / 1503$ & 8/1447 \\
\hline BA 301C3 & 99.67 & --- & $9 / 1447$ \\
\hline E. coli ATCC11775T & 99.45 & 99.38 & --- \\
\hline
\end{tabular}


Table 4. Matrix similarity and nucleotide difference of of 16S rRNA gene sequences of Gram negative bacillus bacteria of Enterobacteriaceae family members on the third clade and reference strain of Ent. cloacae ATCC 23373

\begin{tabular}{|c|c|c|c|c|c|c|}
\hline \multirow[t]{2}{*}{ Isolate Code } & 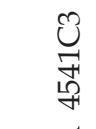 & $\begin{array}{l}\circlearrowright \\
10 \\
8 \\
0\end{array}$ & 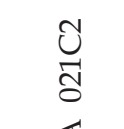 & $\begin{array}{l}\text { U } \\
\underset{\forall}{+} \\
\stackrel{7}{4}\end{array}$ & 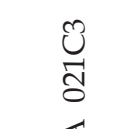 & 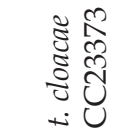 \\
\hline & 『্ & $\underset{G}{U}$ & 仙 & 『 & 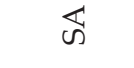 & 这艺 \\
\hline BA4541C3 & --- & $2 / 1500$ & $7 / 1500$ & $6 / 1499$ & $12 / 1499$ & $32 / 1495$ \\
\hline TG035C1 & 99.87 & --- & $5 / 1502$ & $4 / 1501$ & $10 / 1502$ & $30 / 1498$ \\
\hline SA021C2 & 99.53 & 99.67 & --- & $9 / 1501$ & $15 / 1501$ & $31 / 1497$ \\
\hline BA4541C2 & 99.6 & 99.73 & 99.4 & --- & $12 / 1500$ & $32 / 1496$ \\
\hline SA021C3 & 99.2 & 99.33 & 99 & 99.2 & --- & 23/1497 \\
\hline Ent. cloacae ATCC23373 & 97.86 & 98 & 97.93 & 97.86 & 98.46 & --- \\
\hline
\end{tabular}

The number of $16 \mathrm{~S}$ rRNA gene copies in bacteria was various (1-15) in each genome. Each copy had the size approximately 1500 bp. Marchandin et al. (2003) reported that the 16S rRNA gene sequences in each copy of every organism were identical. The nucleotide difference of $16 \mathrm{~S}$ rRNA gene copies was called micro-heterogeneity. The $16 \mathrm{~S}$ rRNA gene sequences in 2 different $16 \mathrm{~S}$ rRNA gene clones from the same isolates showed the presence of nucleotide difference with the similarity value of $99-100 \%$. The results of this study was similar with the findings of Marchandin et al. (2003), that 4 16S rRNA gene copies in one bacterial strain of Veillonilla sp. ADV 360.1 showed two identical gene copies (similarity $100 \%$ ) and two various gene copies (similarity 98.5 to $99.8 \%)$.

The fourth clade consisted of one reference strain of Citrobacter freundii ATCC

Table 5. Matrix similarity and nucleotide difference of 16S rRNA gene sequences of Gram negative bacillus bacteria of Enterobacteriaceae family members on the fifth clade and reference strain of Ser. marcescens ATCC13880

\begin{tabular}{|c|c|c|c|}
\hline Isolate Code & 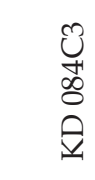 & 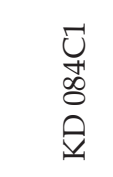 & 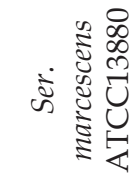 \\
\hline KD084C3 & --- & $3 / 1502$ & $7 / 1488$ \\
\hline KD084C1 & 99.8 & --- & $6 / 1489$ \\
\hline $\begin{array}{l}\text { Ser. marcescens } \\
\text { ATCC13880 }\end{array}$ & 99.53 & 99.6 & --- \\
\hline
\end{tabular}

8090. The fifth clade consisted of $216 \mathrm{~S}$ rRNA gene clones derived from isolate KD 08.4 (similarity 99.53-99.8\%) and one reference strains of Ser. marcescens ATCC 13880 with nucleotide difference number of 3-7 nucleotides, were shown in Table 5.

Based on the nucleotide similarity value, it could be concluded that isolate KD 08.4 was identified as the isolate of Ser. marcescens KD 08.4 included as Ser. marcescens members.

Theconstructed phylogenetic trees based on Neighbor-Joining algorithm ( Saitou and Nei, 1987 ) showed the relationship between 8 isolates of Gram-negative bacillus bacteria obtained from patients' positive Widal blood samples, included to Enterobacteriaceae family isolates which each consisted of 2 $16 \mathrm{~S}$ rRNA gene clones, except isolate TG 03.5, with 5 reference strains (Ser. marcescens ATCC 13880, Cit. freundii ATCC 8090 , Ent. cloacae ATCC 23373, E. coli ATCC 11775T, S. typhi ATCC $19430^{\mathrm{T}}$ ) based on $16 \mathrm{~S}$ rRNA gene sequences. The data showed that the isolates found in positive Widal blood were Ser. marcescens KD 08.4, E. coli BA 30.1, S. typhi BA 07.4, S. typhi KD 30.4, S. typhi SA 02.2, and the isolates of Ent. cloacae SA 02.1, Ent. cloacae BA 45.4.1, Ent. cloacae TG 03.5 which had the closest kinship with Ent. cloacae ATCC 23373. The similarity value of those 8 isolates (15 16S rRNA gene clones) were between 97.86 to $100 \%$, similar to what had been reported by Chang, et al. (1997). 
Besides using numerical systematic based on phenotypic characters and chemical systematic, the bacterial identification could also conducted by using the molecular character systematic based on the nucleic acids, such as based on 16S rRNA genes. 16S rRNA genes were conserved genes which were present in all bacteria, that could be used to classify bacteria based on the kinship relationship. The genomic analysis was better than the protein analysis since it did not rely on certain genomic expression which encoded proteins and might result in phenotypic variation (Priest and Austin, 1995; Vandamme et al., 1996; Giammanco et al., 1999).

The results of phylogenic analysis based on 16S rRNA gene sequences showed that the isolates presented in positive Widal blood were Ser. marcescens KD 08.4 which had close relationship with Ser. marcescens ATCC 13880, E. coli BA 30.1 with E. coli ATCC $11775^{\mathrm{T}}$, S. typhi BA 07.4, S. typhi KD 30.4, and S. typhi SA 02.2 with S. typhi ATCC $19430^{\mathrm{T}}$, and the isolates of Ent. cloacae SA 02.1, Ent. cloacae BA 45.4.1, Ent. cloacae TG 03.5 with Ent. cloacae ATCC 23373. The similarity value of 8 isolates (1516S rRNA gene clones) was between 97.86 to $100 \%$. The Research conducted by Darmawati et al. (2013), showed that the classification based on biochemical characters was congruent with the results of classification based on total protein. This was also congruent with the classification based on 16S rRNA gene sequences. It might happen as the biochemical characteristics was the reflection of enzyme activities. The enzyme was functionally active protein as a result of translated expressed gene in a genome. Thus, the classification combining between the classification based on phenotypic, chemical, and molecular might result in accurate classification.

\section{Acknowledgments}

The author would like to thank the Directorate General of Higher Education, Ministry of National Education of the
Republic of Indonesia who had provided funding for the research in sandwich like program of 2012. The author would also like to convey her deepest gratitude to Nara Institute of Science and Technology (NAIST) for the opportunity given in conducting this research.

\section{Reference}

Anonymous. 2007. Profile Health status of Province South Sulawesi, Indonesia. Ministry of of Health, Republic of Indonesia

Anonymous. 2008. Profil Kesehatan Kota Semarang 2008. Dinas Kesehatan. J1. Pandanaran 79. Semarang

Beig, F. K., F. Ahmad, M. Ekram, I. Shukla., 2010. Typhidot M and Diazo test vis-à-vis blood culture and Widal test in the early diagnosis of typhoid fever in children in a resource poor setting. Braz J. of Inf. Dis, 14 (6): 589-593.

Chang, H. R., L. H. Loo, K. Jeyaseelan, L. Ernest and E. Stackebrandt., 1997. Phylogenetic Relationships of Salmonella typhi and Salmonella typhimurium Based on 16S rRNA Sequence Analysis. Int. J. of Syst. Bacteriol, 47 (4): 1253-1254

Darmawati, S. L. Sembiring, W. Asmara, W. T. Artama. 2012. Bacteria Species Diversity of Positive Widal Blood cultures from Semarang Based Phenotypic characters. Proceedings of the National Seminar on Biology of Sebelas Maret University of Surakarta.

Darmawati, S. L. Sembiring, W. Asmara, W. T. Artama, S. Syaiful. 2013. Chemosystematic of Enterobacteriaceae Familia Obtained from Blood Cultures Based on Total Protein Profiled. Ind. J. of Biotechnol, 18 (1): 58-63

Fadeel, M. A., B. L. House, M. M. Wasfy, J. D. Klena, E. E. Habashy, M. M. Said, M. A. Maksoud, B. A. Rahman \& G. Pimentel., 2011. Evaluation of a newly developed ELISA against Widal, TUBEX-TF and Typhidot for typhoid fever surveillance. J. of Inf. in Dev. Countries, 5(3): 169-175 
Giammmanco, G., S. Pignato \& G. M. Giammanco., 1999. Recent trends in Salmonellosis epidemiology. J. of Prevent. Med. and Hygiene, 40: 19-24

Khoharo, H. K., S. Ansari, F. Qureshi., 2010. Evaluating Single Acute-phase Widal test for the diagnosis of Typhoid Fever. Medical Channel, 16 (1): 42-44

Ley, B., G. Mtove, K. Thriemer, B. Amos, L. Seidlein, I. Hendriksen. A. Mwambuli, A. Shoo, R. Malahiyo S. M. Ame, D. R. Kim, L. R. Ochial, J. D. Clemens, H. Reyburn, H. Wilfing, S. Magesa \& J. L. Deen., 2010. Evaluation of the Widal tube agglutination test for the diagnosis of typhoid fever among children admitted to a rural hospital in Tanzania and a comparison with previous studies. Bio Med Central Infectious Diseases, 10:180

Marchandin, H., C. Teyssier, M. S. de Buochberg, H. Jean-Pierre, C. Carriere \& E. Jumas-Bilak., 2003. Intra-chromosomal heterogeneity between the four 16S rRNA gene copies in the genus Veillonella: implications for phylogeny and taxonomy

Novianti, T., 2006. Examination of AntiSalmonella typhi IgM for Typhoid Fever Diagnosis Laboratory Information. ISSN 0854-7165. No. 5/2006.

Priest, F. and B. Austin. 1993. Modern Bacterial Taxonomy. Second edition. Chapman and hall. London

Saitou, N. and M. Nei., 1987. The neighborjoining method: a new method for Reconstructing phylogenetic trees. $\mathrm{Mol}$ Biol Evol, 4 (4): 406-425

Vandamme, P., B. P. M. Gillis, P. De Vos, K. Kerstres and J.Swings., 1996. Polyphasic Taxonomy, a consensus approach to bacterial systematic. Microbiol Rev, 60 (2): 407-438

Volgstein, B., and D. Gillespie., 1979. Preparative and analytical purification ofDNA from agarose. Proc. Natl. Acad. Sci. U.S.A. 76:615-619. 